\title{
Patterns of Cell Polarity and Chromosome Segregation in Chains of Sporulating Bacillus megaterium
}

\author{
By ANTHONY D. HITCHINS $\dagger$ \\ Thomas Hunt Morgan School of Biological Sciences, University of Kentucky, \\ Lexington, Kentucky 40506, U.S.A.
}

(Received 2 January 1980; revised 1 April 1980)

\begin{abstract}
The asymmetry of the DNA duplex due to polynucleotide strand complementarity could be the molecular basis of cell polarity in spore-forming bacteria. To test this possibility, the relationship of DNA strand segregation to the spore location pattern in chains of sporangia was investigated in Bacillus megaterium. Spores containing one chromosome labelled in one of the complementary strands were formed from cells that had been allowed to segregate pulse-labelled chromosomes in minimal medium at $30^{\circ} \mathrm{C}$. A second crop of spores was then formed from cells originating from the labelled spore population. The second generation spores inherited labelled strands from the first spore population by random segregation. In contrast, the patterns of spore positions in sporangial chains were nonrandom. Furthermore, the non-randomness of patterning was stable and was unaffected by growth temperature $\left(15\right.$ to $\left.37^{\circ} \mathrm{C}\right)$ or by enrichment of the minimal medium used in the segregation experiments. Since the pattern of DNA strand segregation is random and the spore location pattern in chains of sporangia is non-random, the asymmetry of the DNA duplex cannot be the determinant of cell polarity.
\end{abstract}

\section{INTRODUCTION}

While cell polarity and the development of pattern are usually regarded as unique characteristics of eukaryote development, they are also exhibited by prokaryotes which possess primitive developmental systems (Konigsberg, 1979). The spore-forming bacilli produce morphologically asymmetric cells when they sporulate. A single intracellular spore is initiated at one pole of the rod-shaped sporangium by means of an asymmetric cell division. In Bacillus megaterium the spore loci in chains of sporangia are non-randomly located and form a geometrically simple pattern (Hitchins, 1975, 1978b). The occurrence of cell polarity in a primitive organism such as $B$. megaterium makes it a useful prototype for investigating the principles that may be fundamental to these developmental phenomena in higher organisms.

The spores in chains of $B$. megaterium sporangia are located distally to the most recent vegetative cell division septa (Hitchins, 1975; Johnstone \& Ellar, 1978). This suggests that there is a polarity in the presporangium that influences the subsequent position of the asymmetric prespore septum. The source of the asymmetry and the cell polarity observed in chains of bacteria could be related to the mechanism of cell division since the asymmetric septation of sporulation may be a modification of the symmetric septation that occurs during vegetative cell division (Doi, 1977; Ellar, 1978; Freese et al., 1978; Hitchins, 1978 a; Hitchins \& Slepecky, 1969). The patterns of spore loci demonstrate that there is a regular

† Present address: Laboratory of Molecular Biology, National Institute of Neurological and Communicative Disorders and Stroke, National Institutes of Health, Bethesda, Maryland 20205, U.S.A. 
topological relationship between the asymmetric sporulation septa and the symmetric vegetative septa in chains of spore-forming cells. Therefore, it is logical to search initially for a source of asymmetry in the cell division process that could be expressed when sporulation is induced by nutrient deprivation. One such source is the DNA duplex which is structurally asymmetric. This asymmetry could lead to differential behaviour and expression of the sporangial chromosomes prior to asymmetric septation. DNA asymmetry would thus be the basis for the subsequent differences between the two ends of the sporangium. One way in which the asymmetry could be manifested is as a non-random pattern of DNA segregation with respect to chromosome age.

A previous study showed that old chromosomes of $\boldsymbol{B}$. megaterium segregate into spores and mother cell compartments of sporangia at random and independent of the spore loci patterning in sporangial chains (Hitchins, 1978b). However, age-independent chromosome segregation could still be compatible with an age-dependent strand-specific segregation pattern (Hitchins, 1976). Thus, the chemical specificity of the complementary polynucleotide strand containing the marker label in an old chromosome may be an important factor in the detection of non-random segregation. The results of experiments to test this hypothesis are reported here. They show that segregation into spores is random with respect to strand-specificity, suggesting that the asymmetry of DNA due to strand complementarity cannot account for patterns of spore loci in chains of $B$. megaterium.

\section{METHODS}

Bacteria. The organism used was a thymine auxotroph of Bacillus megaterium ATCC 19213.

Growth and sporulation conditions. Cultures were prepared by inoculating heated $\left(70{ }^{\circ} \mathrm{C} ; 30 \mathrm{~min}\right)$ spores into $50 \mathrm{ml}$ sucrose/salts medium containing $0.5 \%$ (w/v) sucrose (Slepecky \& Foster, 1959), $100 \mu \mathrm{g} \mathrm{L-alanine}$ $\mathrm{ml}^{-1}, 100 \mu \mathrm{g}$ inosine $\mathrm{ml}^{-1}$ and $50 \mu \mathrm{g}$ thymine $\mathrm{ml}^{-1}$. Actively growing cells were sedimented and resuspended in $25 \mathrm{ml}$ sucrose/acetate/salts sporulation medium containing $0.1 \%(\mathrm{w} / \mathrm{v})$ sucrose, $0.1 \%(\mathrm{w} / \mathrm{v})$ sodium acetate and $2 \mu \mathrm{g}$ thymine $\mathrm{ml}^{-1}$. Cultures were shaken in side-arm flasks in a water bath at $30^{\circ} \mathrm{C}$. Culture turbidity was monitored spectrophotometrically at $600 \mathrm{~nm}$.

Spore frequency and polarity indices. The sporulation frequency was expressed as the percentage of cells containing phase bright spores at peak refractility; at least 100 cells per sample were examined.

Polarity was measured as described previously by an index defined in percentage units (Hitchins, 1978b). The polarity index is the percentage of spores occupying the positions expected when each spore is preferentially located at the old end of its sporangium as in B. megaterium (Hitchins, 1975). Arbitrarily beginning at the left end of a chain, the successive spore loci will alternate regularly among the left and right sporangial poles as a chain is inspected from left to right. Thus in Fig. 1 (top row) the left, right, left, right pattern of terminal spore location corresponds to a polarity index of $100 \%$, i.e. an exact correspondence with the ideal pattern. Asporogenous cells and chains with odd numbers of sporangia can lead to an underestimate of the index, but this error is insignificant for $B$. megaterium grown in sucrose/salts medium (Hitchins, 1975, 1978b). Patterns differing from the B. megaterium pattern will yield polarity indices much less than $100 \%$, as shown in the other examples in Fig. 1.

Collection and processing of sporangia and spores. Samples of young sporangia were collected about $1.5 \mathrm{~h}$ after growth ceased. The samples were hydrolysed with warm alkali or hot acid as described below. Spore samples were obtained after sporangial autolysis, unless stated otherwise. The spores were incubated at $35^{\circ} \mathrm{C}$ for $60 \mathrm{~min}$ with $200 \mu \mathrm{g}$ chicken egg-white lysozyme $\mathrm{ml}^{-1}$ (EC 3.2.1.17) and $100 \mu \mathrm{g}$ bovine pancreatic deoxyribonuclease $\mathrm{ml}^{-1}$ (EC 3.1.21.1) to release and degrade any residual extrasporal DNA present in either the unlysed cells or the culture fluid. The enzyme-treated spores were then subjected to the same chemical hydrolyses as the sporangia. Identical amounts of the hydrolases were added to the sporangia just after addition of the acid or alkali but prior to the incubations in order to maintain a constant concentration of added protein in all samples.

$P u / s e^{2}$ radiolubelling of $D N A$. Cells in the exponential phase of growth were labelled with [methyl $\left.{ }^{3} \mathrm{H}\right]$ thymidine. The cells in a $50 \mathrm{ml}$ culture with a density corresponding to $0.2 A_{600}$ units were concentrated by centrifugation at $5^{\circ} \mathrm{C}$. The cell pellet was suspended in $2 \mathrm{ml}$ sucrose/salts medium containing [methyl $\left.{ }^{3} \mathrm{H}\right]-$ thymidine $\left[0.1 \mathrm{mCi} ; 52 \mathrm{Ci} \mathrm{mmol}^{-1}\left(1.92 \mathrm{TBq} \mathrm{mmol}^{-1}\right)\right]$ and excess sucrose $(0.5 \% \mathrm{w} / \mathrm{v})$ and the suspension was incubated at $30^{\circ} \mathrm{C}$ for $8 \mathrm{~min}$. Labelled cells were used immediately for segregation experiments.

Assay of radiolabelled DNA. The amount of label in the DNA of sporangia and spores was expressed as 


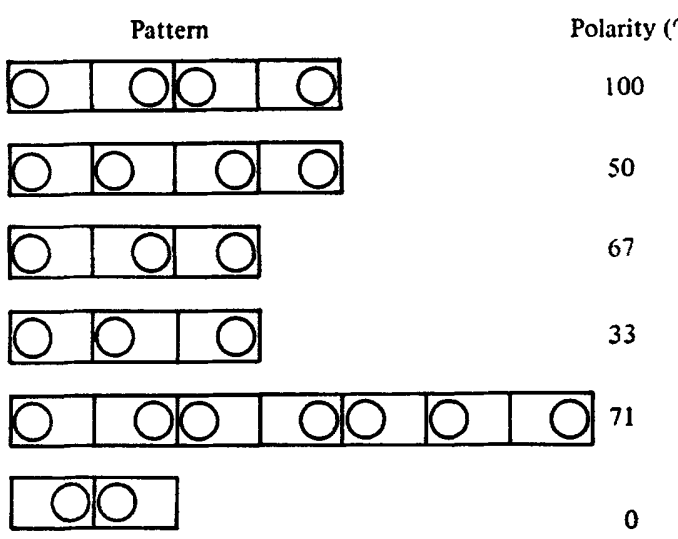

Fig. 1. Pattern types and the corresponding polarity indices. Polarity indices were calculated as described in Methods. The indices are a measure of the direction of sporangial polarization and hence patterning. An example of $100 \%$ polarity is shown in the top panel and is the standard reference pattern since it occurs with high frequency in $B$. megaterium. Although the chains with three sporangia have low indices (33 or 67) the patterns are consistent with the standard pattern, as explained elsewhere (Hitchins, 1975). Such chains were infrequent enough not to lower the average polarity index below $85 \%$ in the growth conditions used in the present study. The other examples are illustrative only.

the radioactivity (c.p.m.) in the alkali-resistant portion of the hot acid-soluble macromolecular fraction. The amount of label in the DNA equals the radioactivity in the cold acid-precipitable part of the alkaliresistant fraction minus the radioactivity in the cold acid-precipitable part of the hot acid-resistant fraction.

The amount of cold acid-precipitable material in the alkali-resistant fraction was determined as follows. Quadruplicate samples of suspensions of the various cell forms were mixed with equal volumes of $2 \mathrm{M}-\mathrm{KOH}$ and incubated at $35^{\circ} \mathrm{C}$ for $20 \mathrm{~h}$. The alkali digests were cooled to $0{ }^{\circ} \mathrm{C}$ and neutralized with cold $2 \mathrm{M}-\mathrm{HCl}$. Each neutralized digest was mixed with an equal volume of cold $10 \%(\mathrm{w} / \mathrm{v})$ trichloroacetic acid (TCA), and after $30 \mathrm{~min}$ at $0{ }^{\circ} \mathrm{C}$ the precipitate was collected on a nitrocellulose filter (Millipore, $0.45 \mu \mathrm{m}$ pore size). The loaded filters were washed three times with $5 \mathrm{ml}$ cold $5 \%$ TCA containing $100 \mu \mathrm{g}$ thymine $\mathrm{ml}^{-1}$ and $100 \mu \mathrm{g}$ thymidine $\mathrm{ml}^{-1}$.

The amount of cold acid-precipitable material in the hot acid-resistant fraction was obtained by heating quadruplicate samples with $0.5 \mathrm{M}-\mathrm{HClO}_{4}$ at $80^{\circ} \mathrm{C}$ for $3 \mathrm{~h}$. Hydrolysed samples were cooled to $0{ }^{\circ} \mathrm{C}$ and mixed with equal volumes of cold $10 \%$ TC.A. After $30 \mathrm{~min}$ at $0^{\circ} \mathrm{C}$ the precipitates were collected and processed as described above. Dried filters were radioassayed in glass vials containing Econofluor scintillation fiuid (New England Nuclear).

Segregation procedure. Cells containing pulse-labelled DNA were grown in sucrose/acetate/salts medium for 1 to 6 generations before being permitted to sporulate. The final density of the sporangial suspensions was similar in order to maintain an approximately constant dry weight on each filter. This was achieved by varying the initial cell densities while maintaining a constant initial concentration of growth limiting substrate (sucrose). Batches of sporangia were produced that contained pulse-labelled chromosomes of different ages. Chromosome ages were defined as the number of turbidimetrically determined cell generations of post-labelling segregation.

The DNA made subsequently to DNA pulse-labelled with [methyl- ${ }^{3} \mathrm{H}$ ] thymidine was differentially and continuously labelled with [2-11 C]thymine $\left[1 \mu \mathrm{Ci} ; 53 \mathrm{mCi} \mathrm{mmol}{ }^{-1}\left(1.96 \mathrm{GBq} \mathrm{mmol}^{-1}\right)\right]$. By using a double label technique no correction for sporulation frequency was required to estimate the relative amount of pulse-labelled [ $\left.{ }^{3} \mathrm{H}\right] \mathrm{DNA}$ segregating into spores. The ratios of ${ }^{3} \mathrm{H} /{ }^{14} \mathrm{C}$ in spore DNA and in the total DNA of the young sporangia were compared. Any preferential segregation of pulse-labelled [ $\left.{ }^{3} \mathrm{H}\right] \mathrm{DNA}$ into the mother cell or the spore would be indicated by a change in the ${ }^{3} \mathrm{H} /{ }^{14} \mathrm{C}$ ratio. Segregation of the $\left[{ }^{14} \mathrm{C}\right] \mathrm{DNA}$ to the level of one strand per cell cannot occur because exogenous $\left[{ }^{14} \mathrm{C}\right.$ ] thymine is present continuously during the segregation of the $\left[{ }^{3} \mathrm{H}\right] \mathrm{DNA}$. Thus the ${ }^{3} \mathrm{H} /{ }^{14} \mathrm{C}$ ratio is proportional to the specific radioactivity of $\left[{ }^{3} \mathrm{H}\right] \mathrm{DNA}$ per unit mass of total DNA. 


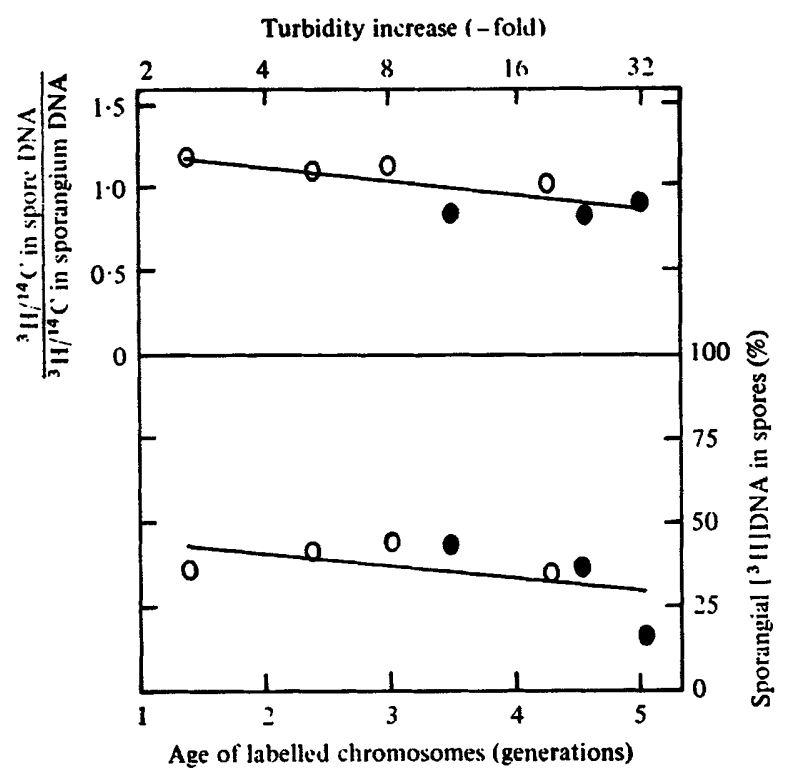

Fig. 2. Demonstration of chromosome age independence of segregation of pulse-labelled chromosomes into spores. Cells containing chromosomes pulse-labelled with $\left[\mathrm{methy} /{ }^{3} \mathrm{H}\right]$ thymidine were permitted to segregate DNA strands for up to five generations in sucrose/acetate/salts medium at $30^{\circ} \mathrm{C}$. During segregation the cells were continuously labelled with $\left[2-{ }^{14} \mathrm{C}\right]$ thymine. The ratio of the ${ }^{3} \mathrm{H} /{ }^{14} \mathrm{C}$ value in spore DNA to the ${ }^{3} \mathrm{H} /{ }^{14} \mathrm{C}$ value in the DNA of young sporangia after different periods of segregation was calculated $(a)$. A value of unity indicates no difference between the ${ }^{3} \mathrm{H} /{ }^{14} \mathrm{C}$ ratios of the DNA of spores and of young sporangia. The proportion of sporangial DNA-label segregation into spores $(b)$ was calculated from the ${ }^{3} \mathrm{H}$ radioactivity only. The frequency of sporulation was high but was not measured accurately. The results from two experiments are distinguished by the different symbols. The curves are least squares regression lines.

\section{RESULTS}

Two changes in the chromosome labelling protocol facilitated the test for strand-specific segregation into spores. First, cells had previously been pulse-labelled with radioactive thymine for 0.4 generations (Hitchins, 1978b). In this study labelling with radioactive thymidine increased the level of incorporation of radioactivity during a reduced pulse time of 0.11 generations. The old and new labelling protocols were found to yield similar results. Thus, as the ages of the labelled chromosomes increased to 5.5 generations their probability $(P=0.4$ to 0.5$)$ of segregating into spores did not change significantly. Second, a double radiolabel segregation technique was employed so that the frequency of sporulation did not have to be determined. Chromosomes were pulse-labelled with [methyl- ${ }^{3} \mathrm{H}$ ] thymidine and the DNA formed during the subsequent segregation period was continuously and differentially labelled with $\left[2-{ }^{14} \mathrm{C}\right]$ thymine. As shown in Fig. 2(a), there was only a slight decrease in the probability for pulse-labelled $\left({ }^{3} \mathrm{H}\right)$ chromosomes to segregate into spores relative to the younger continuously labelled $\left({ }^{14} \mathrm{C}\right)$ chromosomes. For comparison of the single and double label methods, Fig. 2(b) demonstrates the same result using only the pulse-label data from the double label experiment and correcting it for the frequency of sporulation.

\section{Strand-specificity of chromosome segregation}

Since the results of experiments using the new and old labelling protocols were similar, the double label technique was used to test for a strand-specific segregation pattern. Exponentially growing cells were pulse-labelled with $\left[\right.$ methyl- $\left.{ }^{3} \mathrm{H}\right]$ thymidine for 0.11 


\section{Table 1. Segregation of pulse-labelled DNA during a second cycle of sporulation}

Young sporangia and spores were obtained and processed as described in Methods. The radioactivity (c.p.m.) in the mother cell fraction was obtained from the difference between that in mature sporangia containing refractile spores and that in the spores released from those sporangia by lysis with lysozyme. The ratio ${ }^{3} \mathrm{H} /{ }^{14} \mathrm{C}$ represents the ${ }^{3} \mathrm{H}$ radioactivity in the old pulse-labelled DNA divided by the ${ }^{14} \mathrm{C}$ radioactivity in newer continuously labelled DNA. In the fourth column, the calculated ratios in the various cell forms are for a random strand segregation pattern; the calculations are based on the averages of the relative empirical ratios for young sporangia in the two experiments taking the values for sporangia as unity. In the fifth column, the theoretical average ratios are presented for a non-random segregation model in which chromosomes with old strands segregate exclusively into the second generation spores.

\begin{tabular}{lcccc} 
& \multicolumn{3}{c}{ Empirical* and theoretical average ${ }^{3} \mathbf{H} /{ }^{14} \mathrm{C}$ ratios } \\
Cell form & Expt 1 & Expt 2 & $\begin{array}{c}\text { Relative } \\
\text { average }\end{array}$ & $\begin{array}{c}\text { Theoretical } \\
\text { average }\end{array}$ \\
Young sporangium & $0.447 \pm 0.090 \dagger$ & $0.379 \pm 0.067$ & 1.00 & 1.00 \\
Spore & $0.382 \pm 0.135$ & $0.340 \pm 0.059$ & 0.88 & 2.00 \\
Mother cell & - & $0.393 \pm 0.096$ & 1.04 & 0.00
\end{tabular}

* Results are the averages of those from four sets of samples; the ranges are the $95 \%$ confidence limits.

$\dagger$ Average and $95 \%$ confidence limits for three sets of samples. Inclusion of the fourth set would give a value of $0 \cdot 378 \pm 0 \cdot 291$. Thus, the fourth set was omitted because it resulted in an atypically high confidence limit: the average confidence limit was \pm 0.09 .

generations. The labelled strands were segregated during further growth in unlabelled medium. Cells were then permitted to sporulate. The spores were released, cleaned and then induced to germinate and form a growing culture. During growth, the new DNA formed was labelled with $\left[2-{ }^{14} \mathrm{C}\right]$ thymine. After a second cycle of sporulation the second crop of spores was isolated and its ${ }^{3} \mathrm{H} /{ }^{14} \mathrm{C}$ ratio was compared with that of the corresponding sporangia. As shown in Table 1, there was no tendency for old $\left[{ }^{3} \mathrm{H}\right] \mathrm{DNA}$ to be selectively incorporated into spores since the proportion of old DNA to new DNA in spores was the same as in their presporangia. This implies that DNA segregation during sporulation is not strand-specific. If the presegregated labelled strands in the first spore crop were composed of only one type of complementary strand, it would be expected that they would have also preferentially segregated into the second spore crop with a concomitant enrichment of old DNA relative to new DNA.

\section{Constancy of cell polarity}

The marked regularity of the spore location pattern in $B$. megaterium is well established (Hitchins, 1975; Johnstone \& Ellar, 1978). The pattern is invariant in the minimal and enriched growth media that have been examined so far, in contrast to the variability seen in B. subtilis (Dunn \& Mandelstam, 1977). In the present study the polarity index was $85 \%$ at $30{ }^{\circ} \mathrm{C}$ in sucrose/acetate/salts medium and it was not significantly affected by enrichment with casein hydrolysate and yeast extract. These values are underestimates since the sporulation frequency, though typically high (90\%), was less than $100 \%$. Furthermore, the polarity index was essentially unaffected by growth temperature in the sporulation temperature range 15 to $37^{\circ} \mathrm{C}$. The maximum growth temperature was about $46^{\circ} \mathrm{C}$, but above $37^{\circ} \mathrm{C}$ the sporulation frequency declined sharply, making it difficult to estimate polarity indices. In contrast, the minimum temperature at which growth was detectable was $15^{\circ} \mathrm{C}$ and sporulation still occurred with high frequency, although spore formation took longer.

\section{DISCUSSION}

It was demonstrated previously that there is no preferential segregation of young versus old chromosomes into the spore and mother cell compartments of the asymmetrically 
divided sporangium of $B$. megaterium (Hitchins, 1978b). The results of the present study show that when the nature of the pulse-labelled strand in an old chromosome is considered, segregation is still random. Although chromosome segregation is random, the spores into which the chromosomes segregate are non-randomly distributed in sporangial chains. Therefore, the patterns of chromosome segregation and spore location are not coincident. The spore location patterning is based on a polarization of the presporangium. The direction of the polarization in $B$. megaterium involves spore localization at the pole distal to the one formed by the symmetric division that occurred just prior to sporulation. The results show that non-random polarization of the sporangium cannot be correlated with one asymmetric facet of DNA, namely, the asymmetry due to strand complementarity.

The results of this study do not rule out DNA strand asymmetry being a contributing factor in cell polarity determination. However, a multi-factor process for polarity determination would be complex and at present it is more economical to look for another determinant of polarity at the non-DNA level. The sporangial cytosol is believed to be homogeneous until some time after the asymmetric division (Freese \& Freese, 1977). Thus the cytosol is not likely to be polarized. This leaves the cell envelope as the most likely source of polarity, and hence patterning, as already suggested by Dunn \& Mandelstam (1977). If so, the sporangial wall and/or membrane would have to retain the information necessary to determine that the spore is located at the end of the sporangium which is old with respect to the end formed by the last cell division septum. In view of the current lack of knowledge of the extent and distribution of topological heterogeneities in the wall and membrane, finding out the way in which the envelope layers could determine polarity presents a formidable problem.

This research was supported by grant no. NP-224 from the American Cancer Society, Inc. Technical assistance was provided by S. O. Teremi. Presentation of part of this research at the XII International Congress of Microbiology, Munich, F.R.G., was facilitated by funds from a grant to the American Society for Microbiology by the Fogarty International Center and funds from the Graduate School of the University of Kentucky.

\section{REFERENCES}

DoI, R. (1977). Genetic control of sporulation. Annual Review of Genetics 11, 29-48.

DunN, G. \& Mandelstam, J. (1977). Cell polarity in Bacillus subtilis: effect of growth conditions on spore positions in sister cells. Journal of General Microbiology 103, 201-205.

ElLAR, D. J. (1978). Spore specific structures and their function. Symposia of the Society for General Microbiology 28, 295-325.

Freese, E. B. \& Freese, E. (1977). The influence of the developing bacterial spore on the mother cell. Developmental Biology 60, 453-462.

Frefse, E., Heinze, J., Mitani, T. \& Freese, E. B. (1978). Limitation of nucleotides induces sporulation. In Spores VII, pp. 277-285. Edited by G. Chambliss \& J. C. Vary. Washington, D.C.: American Society for Microbiology.

Hitchins, A. D. (1975). Polarized relationship of bacterial spore loci to the 'old' and 'new' ends of sporangia. Journal of Bacteriology 121, 518-523.

Hitchiss, A. D. (1976). Spores as potential topological markers in bacterial DNA segregation studies. Journal of Theoretical Biology 58, 97-111.

Hitchins, A. D. (1978a). Polarity and topology of
DNA segregation and septation in cells and sporangia of the bacilli. Canadian Journal of Microbiology 24, 1104-1134.

Hrtchins, A. D. $(1978 b)$. Chromosome age and segregation during sporulation of Bacillus megaterium. Canadian Journal of Microbiology 24, 1227-1235.

Hitchins, A. D. \& Slepecky, R. A. (1969). Bacterial sporulation as a modified prokaryotic cell division. Nature, London 223, 804-807.

Johnstone, K. \& EllaR, D. J. (1978). Spore location patterns in sporulation doublets of Bacillus cereus and Bacillus megaterium, derived from single doublet isolates with differing sporulation geometry. Journal of Bacteriology 133, 1024-1026.

KonigsberG, I. R. (1979). Preface. Determinants of spatial organisation. In 37th Symposium of the Society for Developmental Biology, pp. ix-xix. Edited by S. Subtelny \& I. R. Konigsberg. New York: Academic Press.

SlePECKY, R. A. \& Foster, J. W. (1959). Alterations in metal content of spores of Bacillus megaterium and the effect on some properties. Journal of Bacteriology 78, 117-123. 